\title{
Physaria scrotiformis (Brassicaceae), a New High-Elevation Species from Southwestern Colorado and New Combinations in Physaria
}

\author{
Steve L. O'Kane Jr. \\ Department of Biology, University of Northern Iowa, Cedar Falls, Iowa 50614-0421, U.S.A. \\ steve.okane@uni.edu
}

Abstract. Physaria scrotiformis O'Kane (Brassicaceae) is a newly described, diminutive, long-lived perennial from the upper subalpine-lower alpine zone of the San Juan Mountains of southwestern Colorado. The species grows on windswept, nearly barren exposures of Leadville limestone on West Silver Mesa. The species is another example of a taxon bridging the gap between the synonymized genera Lesquerella S. Watson and Physaria (Nuttall ex Torrey \& A. Gray) A. Gray s. str. Additionally, the following new combinations and changes in status are made and keys are provided where needed: $P$. carinata (Rollins) O'Kane \& Al-Shehbaz subsp. paysonii (Rollins) O'Kane, P. carinata (Rollins) O'Kane \& Al-Shehbaz subsp. pulchella (Rollins) O'Kane, P. didymocarpa (Hooker) A. Gray subsp. Lanata (A. Nelson) O'Kane, P. didymocarpa (Hooker) A. Gray subsp. lyrata (C. L. Hitcheock) O'Kane, P. floribunda Rydberg subsp. osterhoutii (Payson) O'Kane, P. geyeri (Hooker) A. Gray subsp. purpurea (Rollins) O'Kane, P. hitchcockii (Munz) O'Kane \& Al-Shehbaz subsp. confluens (Maguire \& A. H. Holmgren) O'Kane, P. kingii (S. Watson) O'Kane \& Al-Shehbaz subsp. kaibabensis (Rollins) O’Kane, P. kingii (S. Watson) O'Kane \& AlShehbaz subsp. utahensis (Rydberg) O'Kane, P. lepidota Rollins subsp. membranacea (Rollins) O'Kane, P. newberryi A. Gray subsp. yesicola (R. C. Sivinski) O'Kane, and P. saximontana Rollins subsp. dentata (Rollins) O’Kane.

Key words: Brassicaceae, Colorado, IUCN Red List, Lesquerella, North America, Physaria.

High-elevation species of Physaria (Nuttall ex Torrey \& A. Gray) A. Gray are found in Montana, Idaho, Wyoming, Utah, Nevada, and central Colorado in the western United States. These rare species inhabit windswept, fell-field habilats with stony or gravelly substrates formed primarily from limestone, dolomite, or metamorphic derivatives of these. Most other species of the genus grow in arid, usually warm or hol, lower-elevation habitats. In the San Juan Mountains of southwestern Colorado, limestone in the upper subalpine or alpine is rare (Westem Geographics, 1991; Steven et al., 1974). A new species of
Physaria was discovered in these mountains in the summer of 2006 by Ken Heil, Dave Jamieson, and me while conducting the final fieldwork toward the completion of the Flora of the Four Corners project (Heil \& O'Kane, 2003). Recent fieldwork in the Four Corners area (where Arizona, Colorado, New Mexico, and Utah meet) has yielded three other novelties in Physaria: P. pulvinata O'Kane \& Reveal and P. vicina (J. L. Anderson, Reveal \& Rollins) O’Kane \& AlShehbaz at montane elevations (Anderson et al., 1997; O’Kane \& Reveal, 2006), and P. navajoensis (O'Kane) O’Kane \& Al-Shehbaz at lower, drier elevations (O'Kane, 1999). It is not surprising that the botanically little-explored San Juan Mountains would contain another botanical novelty.

New combinations and status changes in Physaria are given following the discussion of the new species in order that they may be included in an upcoming volume of the Flora of North America. These actions are necessitated because of the recent transfer of most species of Lesquerella S. Watson to Physaria (AlShehbaz \& O'Kane, 2002). Distributions given below are summarized in Rollins (1993), Rollins and Shaw (1973), and Holmgren (2005).

Physaria serotiformis O'Kane, sp. nov. TYPE: U.S.A. Colorado: La Plata Co., San Juan Mtns., $\mathrm{S}$ end of West Silver Mesa ca. $0.1 \mathrm{mi}$. N of hiking trail to Cily Reservoir, $37^{\circ} 33.009^{\prime} \mathrm{N}$, $10737.555^{\prime} \mathrm{W}, 11,827 \mathrm{ft} . \quad(3605 \mathrm{~m}), 19$ July 2006, S. L. O'Kane, Jr. 7977 with K. Heil \& D. Jamieson (holotype, MO; isotypes, ARIZ, ASU, BRY, COLO, CS, GH, ISTC, K, NMC, NY, RM, RSA, SJNM, UNM). Figure 1.

Haec species Physariae hemiphysariae (Maguire) O'Kane \& Al-Shehbaz similis, sed ab ea lamina foliari ad petiolum minus subito attenuata atque fructus valvis non compressis distinguitur.

Herbs, long-lived perennials from a simple or sparsely branched underground caudex, to $3.5 \mathrm{~cm} \times$ $8 \mathrm{~mm}$, elongating with age, distally with a short thatch of old leaf bases; stems (0)1 to 5 per plant, $0.8-3 \mathrm{~cm}$, unbranched, purple-green, arising lateral to (beneath) 


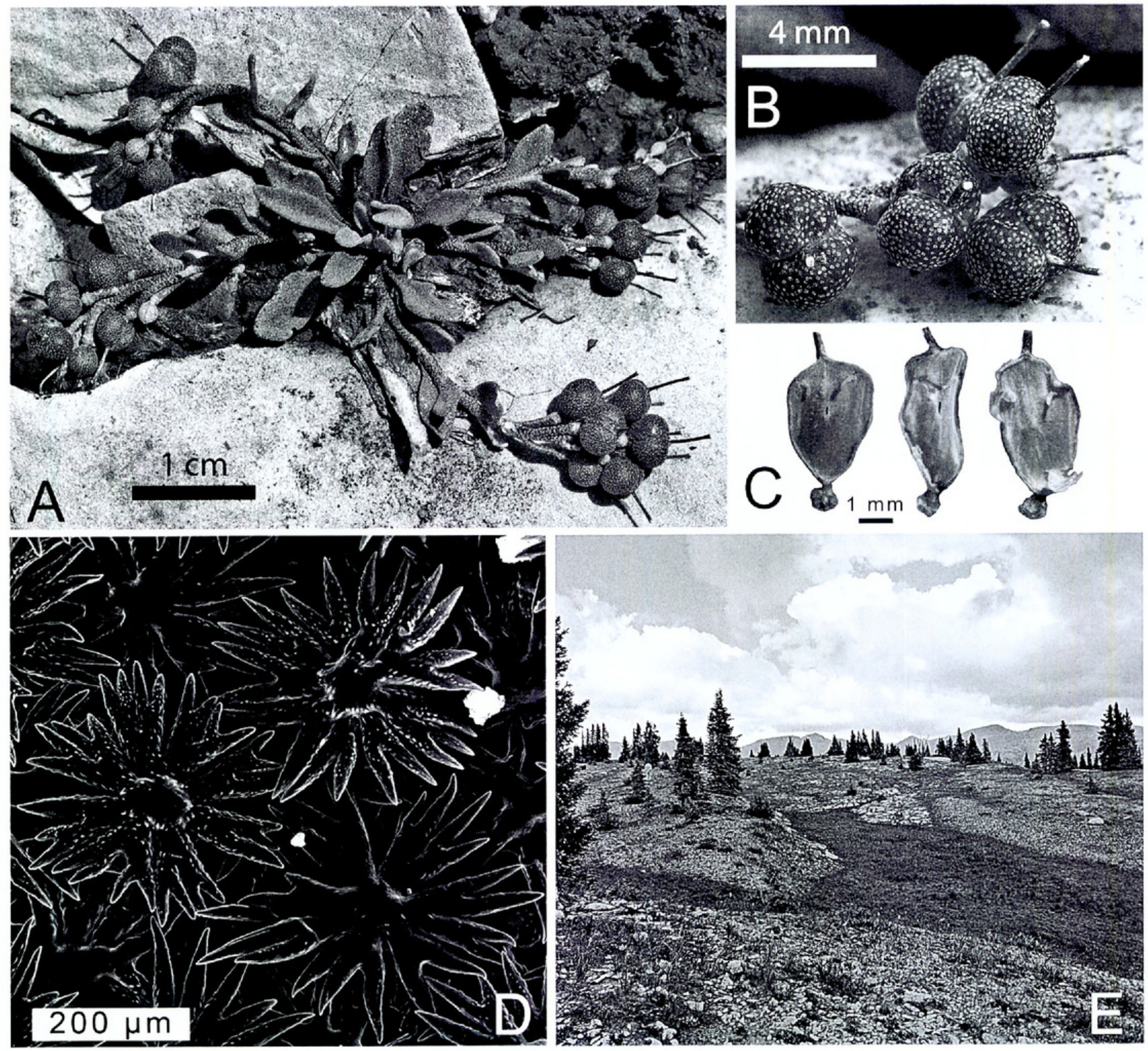

Figure 1. Physaria scrotiformis O'Kane. - A. Plant habit (O'Kane \& Jamieson 8003, ISTC). —B. Silicles (O'Kane \& Jamieson 8003, ISTC). - C. Repla, false septa, and funicles (type O'Kane et al. 7977, MO). Deformity on the right of the center replum is from pressing, and the stigmas have been truncated in the photographs. - D. SEM of adaxial leaf trichomes $\left(O^{\prime} K a n e\right.$ et al. 7977). Bright objects are grains of soil. Note that the lower-level trichomes have fewer tubercles and little or no umbo. - E. View of limestone habitat looking north from the type location (O'Kane et al. 7977) near the City Reservoir Trail. Plants are found on the drier limestone knolls. The ridge in the distance is on average ca. $4.5 \mathrm{~km}$ distant.

the erect or ascending tuft of basal leaves, prostrate to slightly decumbent, from stem tip to stem tip plants to $10 \mathrm{~cm}$, but typically less than $5.5 \mathrm{~cm}$ diam. (Fig. 1A); herbage silvery gray-green to silvery purple, the silver color due to a dense, overlapping covering of small stellate trichomes, these $150-250 \mu \mathrm{m}$ diam., with 5 or 6(7) main rays, each bifurcating, sometimes incompletely so that only 3 tips are present, trichomes short and stout compared to most other species of the genus, ray tips 18 to 29 per trichome, rays moderately tuberculate to nearly smooth, trichome center strongly umbonate to simply low-mounded, those trichomes with more tubercles tending to have larger umbos, the lower layer of trichomes tending to be smoother (Fig. 1D); basal leaves entire, oblanceolate, elliptic or rhombic, mostly flat, sometimes somewhat folded, attenuate at base and tapering to a slightly winged petiole, apex rounded to rounded-acute, including the petiole $0.6-2.7 \mathrm{~cm} \times 2-5 \mathrm{~mm}$, encrusted with trichomes, the basal tuft of leaves to $3(-4) \mathrm{cm}$ diam.; cauline leaves entire, elliptic to oblanceolate, shortpetiolate to essentially entire, 3 to 7 per stem, including the petiole $3-5 \times 1.2-2 \mathrm{~mm}$. Infructescence not elongating appreciably, a raceme with 3 to 7 , \pm crowded fruits, these on straight, ascending pedicels 1.8-3.4 mm long. Flowers not seen. Silicles (Fig. 1B) on stipes $0.2-0.5 \mathrm{~mm}$, ovoid to obpyriform, slightly but obviously didymous (especially in living material), apex rounded, flattened, or even slightly emarginate; base rounded-obtuse; wider than long; 3- 
$4.5 \times 3.7-5 \mathrm{~mm}$, the valves inflated and a little wider than the replum; valves glabrous within, the exterior with scattered trichomes; becoming purple or greenish purple at maturity; ovules 2 or 3(4) per locule (Fig. 1C), these attached to the upper 1/5-2/5 of the replum, within a locule typically 1 on each side or 2 on one side and 1 on the other; false septum entire or medially small-perforate (Fig. IC); replum obovate to rounded-obdeltoid, rounded to obtuse or truncate at the apex; styles linear, 2-3.6 mm, including the truncate stigma, which is the same width as the style: seeds (1)2 to 3 per locule, entirely filling the locule, flattened, typically rounded on one side and \pm flat or concave on the other, relatively plump, purple-brown, ovate to suborbicular, $1.9-2.2 \times 1.6-2 \mathrm{~mm}$, apparently not mucilaginous (although examined seed may have been slightly immature), wingless; colyledons accumbent.

Etymology and ecology. Physaria scrotiformis (meaning "pouch-shaped," referring to the inflated, pubescent, seed-filled, and somewhat didymous fruits), the "West Silver bladderpod," is known only from the southern portion of West Silver Mesa from the City Reservoir hiking trail north to where the cap of Mississippian-age Leadville limestone (or less probably Ouray limestone) ends (Steven et al., 1974). Its habitat consists of fellfield-like windblown. cobbly and gravelly limestone outcrops in a matrix of Picea engelmannii Parry ex Engelmann islands and tundra and upper subalpine vegetation (Fig. 1E). Associates on the nearly barren spots where the species occurs include Minuartia obtusiloba House, Zigadenus elegans Pursh. Castilleja haydenii (A. Gray) Cockerell, Pseudocymopterus montanus J. M. Coulter \& Rose, Poa alpina L., Hymenoxys grandiflora (Torrey \& A. Gray) K. F. Parker, Allium geyeri S. Watson, Townsendia rothrockii A. Gray, and Trisetum spicatum (L.) K. Richter. The plants grow in shallow soil between gray and tan-gray limestone cobbles (Fig. 1A) or gravels. Similar limestone habitats on Lime Ridge to the west were searched unsuccessfully for the species. It is likely that $P$. scrotiformis is limited to West Silver Mesa. No flowers were found at the time of collection, even after diligent searching for late-blooming individuals. The species probably flowers in late June or early July. Among species of Physaria, however, attributes of the flower vary little and are seldom diagnostic unless they are exceptionally large, e.g., P. pulchella (Rollins) O'Kane \& AlShehbaz, or are white rather than the nearly ubiquitous yellow, e.g., P. purpurea (A. Gray) O'Kane \& Al-Shehbaz.

IUCN Red list category. Although rare, this new species is probably nol currently endangered by direct human activities because the whole of its habitat is contained within the Weminuche Wilderness Area. With no appropriate contiguous or nearby limestone substrate at higher elevations to allow for population migration, however, global warming could present a real threat to the species, especially if vegetation types at lower elevations were to invade the inhabited sites. Based on the limited aerial extent of the known (and perhaps only) metapopulation of this species, it can be listed according to IUCN Red List criteria (2001) as EN (Endangered) under Criterion B2a.

Taxonomy and relationships. Morphologically, Physaria scrotiformis bridges the nebulous divide between the traditional, and now-synonymized, genera Lesquerella and Physaria s. str. in that its fruits are somewhat inflated and slightly didymous (Fig. IB). Mulligan (1968) postulated that Physaria could be distinguished from Lesquerella in having the replum narrower than the valves rather than as wide as the valves as in Lesquerella. Although the valves of $P$. scrotiformis are clearly (but slightly) wider than the replum, it is hard to imagine that it could have been included in Physaria s. str. Several other species bridge the Lesquerella/Physaria gap in their fruit morphology: P. cordiformis Rollins, P. geyeri (Hooker) A. Gray, P. obcordata Rollins, P. hemiphysaria (Maguire) O’Kane \& Al-Shehbaz, and P. wyndii (Rollins \& E. Shaw) O'Kane \& Al-Shehbaz are good examples. Physaria inflata (Rollins \& E. A. Shaw) O'Kane \& Al-Shehbaz is especially close to Physaria s. str. in its strongly inflated, balloon-like, thin-walled silicles about $1 \mathrm{~cm}$ long, which are sometimes slightly didymous as well. Consequently, and as argued in AlShehbaz and O'Kane (2002), Lesquerella and Physaria cannot be maintained as separate genera based on any known criteria. One might reason that the silicles of $P$. scrotiformis are not inherently subdidymous, but, rather, they appear so because of being filled with seeds that fully occupy and physically expand the valves. However, fruits with aborted ovules have the same shape as those with seeds. Physaria scrotiformis is probably most closely related to $P$. hemiphysaria from Utah on the Wasatch and West Tavaputs Plateaus and the southwestern rim of the Uinta Basin. They both share a similar leaf shape (wider and more rhombic in $P$. hemiphysaria) and both have subdidymous fruits, these being inflated and with rounded valves in $P$. scrotiformis and little-inflated and angustiseptate-compressed in $P$. hemiphysaria. A relationship to $P$. arctica (Wormskjöld ex Hornemann) O'Kane \& Al-Shehbaz also seems probable based on leaf shape; purplish, somewhat inflated fruits with trichomes absent or scattered; and an analogous habitat that is alpine rather than arctic. Physaria 
scrotiformis has much shorter stems and infructescences, however, being less than $3 \mathrm{~cm}$ long rather than up to $30 \mathrm{~cm}$ long in $P$. arctica. Both species share similar nearly barren limestone habitats. This relationship is not surprising given the known longdistance disjunctions between the San Juan Mountains and the northern Rocky Mountains or the Arctic, e.g., Bupleurum americanum J. M. Coulter \& Rose (Apiaceae), Corydalis caseana A. Gray (Fumariaceae/ Papaveraceae), Huperzia haleakalae (Brackenridge) Holub (Lycopodiaceae), Salix serrisima (Bailey) Fernald (Salicaceae) (see Weber, 2003).

Paratype. U.S.A. Colorado: La Plata Co., SW end of West Silver Mesa just E of where the trail descends to Virginia Gulch, 11,687 ft. (3562 m), 20 July 2006, S. L. O'Kane Jr. \& D. Jamieson 8003 (BRY, COLO, ISTC, MO. SJNM).

\section{New Combinations and Status Changes}

The following novel combinations and status changes are necessitated by both the recent transfer of most species of Lesquerella to Physaria (Al-Shehbaz \& O’Kane, 2002) and because subspecies are favored over varieties for an upcoming volume of the Flora of North America (Al-Shehbaz, pers. comm.).

\section{PhYSARIA CARINATA}

Physaria carinata (Rollins) O'Kane \& Al-Shehbaz subsp. paysonii (Rollins) O’Kane, comb. el stat. nov. Basionym: Lesquerella paysonii Rollins, Contr. Gray. Herb. 171: 44. 1950. TYPE: U.S.A. Wyoming: Lincoln Co., mtns. near Cottonwood Lake, E of Smoot, Payson \& Armstrong 3816 (holotype, GH; isotypes, COLO, MO).

Physaria carinata (Rollins) O'Kane \& Al-Shehbaz subsp. pulchella (Rollins) O'Kane, comb. et stat. nov. Basionym: Lesquerella pulchella Rollins, Novon 5: 72. 1995. TYPE: U.S.A. Montana: Beaverhead Co., barren calcareous soil in open spruce woodland on S-facing slope along Trapper Creek just $\mathrm{S}$ of Hecha Mines, Pioneer Mtns., T3S R11W, Sec. 32, 8600 ft., Peter Lesica $5.525 \&$ Steve Cooper (holotype, GH; isotype, MONTU).

Physaria carinata is notable for its strongly angustiseptate fruits with valves that are pubescent on both the exterior and interior. Recent collections from east-central Idaho show intergradation between and among subspecies paysonii, subspecies pulchella, and subspecies carinata. The later taxon was already noted to be synonymous with subspecies languida, as Lesquerella carinata Rollins var. languida Rollins (AIShehbaz \& O'Kane, 2002). All three taxa can easily be accommodated in an expanded concept of $P$. carinata at the subspecific level. The three often-sympatric subspecies of $P$. carinata can be distinguished as follows, but intergrades appear to be common.

\section{Key to the Subspecies of Physaria Carinata}

la. Silicles with valves evidently sharply keeled; silicles ellipsoid to orbicular; valve margins completely covering the replum edges.

2a. Silicles nearly orbicular to broadly elliptic, rounded above and below ........... .......... c. carinata subsp. pulchella

2b. Silicles ellipsoid, the apex \pm acute, the base narrow-rounded to acute . . . . . . . . . ......... P. carinata subsp. carinata

1b. Silicles with valve margins thin but clearly rounded; silicles ellipsoid; valve margins not completely covering the replum margins. . . . . . . ............. Parinata subsp. paysonii

\section{PHYSARIA DIDYMOCARPA}

Physaria didymocarpa (Hooker) A. Gray subsp. lanata (A. Nelson) O'Kane, stat. nov. Basionym: Physaria didymocarpa var. lanata A. Nelson, Bull. Torrey Bot. Club 31: 241. 1904. TYPE: U.S.A. Wyoming: Big Horn Co., rocky slopes, head of Middle Fork of Powder R[iver], 19 July 1901, Gooding 326 (holotype, RM; isotypes, GH, NY, US).

Physaria didymocarpa (Hooker) A. Gray subsp. lyrata (C. L. Hitchcock) O'Kane, stat. nov. Basionym: Physaria didymocarpa var. lyrata C. L. Hitcheock, Univ. Wash. Publ. Biol. 17: 530. 1964. TYPE: U.S.A. Idaho: Lemhi Co., in talus along E slope of Salmon Mtns., near mouth of North Fork Williams Creek, I July 1945, C. L. Hitchcoch 14305 \& C. V. Muhlick (holotype, WTU).

A key to the varieties (here subspecies) of Physaria didymocarpa is given in Rollins (1993). Here. however, I am recognizing $P$. integrifolia (Rollins) Lichvar at the species rank rather than as $P$. didymocarpa var. integrifolia Rollins.

\section{PHYSARIA FLORIBUNDA}

Physaria floribunda Rydberg subsp. osterhoutii (Payson) O'Kane, stat. nov. Basionym: Physaria osterhoutii Payson, Ann. Missouri Bot. Gard. 5: 146. 1918. TYPE: U.S.A. Colorado: Grand Co. Kremmling, June 1907, G. E. Osterhout 3477 (holotype, NY; isotype, NY).

A key to the two infraspecific taxa of Physaria floribunda is given in Rollins (1993), where both were considered at the varietal rank. Although the two subspecies of $P$. floribunda do morphologically 
approach one another, P. floribunda subsp. osterhoutii has a limited distribution in Grand, Park, and Routt Counties, Colorado, and seems not to intergrade with the typical variety in the vicinity.

\section{PHYSARLA GEYERI}

Physaria geyeri (Hooker) A. Gray subsp. purpurea (Rollins) O'Kane, stat. nov. Basionym: Physaria geyeri (Hooker) A. Gray var. purpurea Rollins, Rhodora 41: 401. 1939. TYPE: U.S.A. Idaho: Custer Co., Challis Creek, 25 July 1916, E. B. Payson 3448 (holotype, GH; isotype, NY).

A key to the two varieties of Physaria geyeri is given in Rollins (1993), which distinguishes these two taxa now recognized at the subspecific rank.

\section{PhYSARIA HITCHCOCKII}

Physaria hitcheockii (Munz) O'Kane \& Al-Shehbaz subsp. confluens (Maguire \& A. H. Holmgren) O'Kane, comb. nov. Basionym: Lesquerella hitchcockii Munz subsp. confluens Maguire \& A. H. Holmgren, Madroño 11: 174. 1951. TYPE: U.S.A. Nevada: Nye Co., ridge $\mathrm{N}$ of Cherry Creek Pass, Quinn Canyon Range, 7000 ft., 20 June 1945, B. Maguire \& A. H. Holmgren 25534 (holotype, NY; isotypes, CAS, MO, POM, UC, US).

Previously Al-Shehbaz and I (2002) treated Lesquerella rubicundula Rollins as one of two subspecies of Physaria hitchcoctii (subsp. rubicundula (Rollins) O'Kane \& Al-Shehbaz). It is clear that a third infraspecific taxon of $P$. hitchcockii requires recognition as indicated by Holmgren (2005). The three subspecies of $P$. hitchcockii may be distinguished as follows.

\section{Key to the SUbspecies of PhrsaR/A HTChCOCKII}

la. Lowermost leaves differentiated (sometimes weakly) into a blade and petiole, blade oblanceolate to obovate; caudex elongated and elastic or not: Nevada and the Table Cliff Plateau, Utah.

2a. Plants with elongate, elastic caudex branches, forming loose mats; silicles $1.7-3 \mathrm{~mm}$ wide: Grant, Quinn Canyon, and Schell Creek Ranges, Nevada . . P. hitchcockii subsp. confluens

2b. Plants with a short, branched caudex, not elongated or elastic, forming small tufted mats; silicles 1.4-1.5(-2) $\mathrm{mm}$ wide; Table Cliff Plateau, Utah (limited to the white member of the limestone Claron Formation) and limestones of the Sheep Range and Spring Mountains of Nevada ... . . . . . . . . ........ P. hitchcockii subsp. hilchcockii

1b. Lowermost leaves with not a hint of differentiation between petiole and blade, blade linear-oblanceolate; raudex elongated and elastic; Paunsaugunt.
Aquarius, and Markagunt Plateaus, Ulah (limited to the pink member of the limestone Claron Formation) ...... P. hitchcockii subsp. rubicundula

\section{PHYSARIA KINGII}

Physaria kingii (S. Watson) O'Kane \& Al-Shehbaz subsp. kaibabensis (Rollins) O'Kane, stat. nov. Basionym: Lesquerella kaibabensis Rollins, Contr. Gray Herb. 211: 110. 1982. Physaria kaibabensis (Rollins) N. H. Holmgren, Brittonia 56(3): 247. 2004. TYPE: U.S.A. Arizona: Coconino Co., $18.6 \mathrm{mi}$. S of Jacob Lake on rd. to the $N$ entrance to Grand Canyon Natl. Park, 8 June 1979, R. C. Rollins \& K. W. Rollins 79191 (holotype, GH; isotypes, BRY, MO, NY, UC, US).

Physaria kingii (S. Watson) O'Kane \& Al-Shehbaz subsp. utahensis (Rydberg) O'Kane, comb. el stat. nov. Basionym: Lesquerella utahensis Rydberg, Bull. Torrey Bot. Club 30: 252. 1903. TY PE: U.S.A. Utah: Utah Co., American Fork Canyon, $9000 \mathrm{ft} ., 31$ July 1880, M. E. Jones 1354 (holotype, NY; isotypes, DS, MO, POM, US).

Welsh (2003: 289) noted that the "Is]egregation of $P$. kingii from $P$. wardii is tenuous...." Holmgren (2005), also recognizing the overwhelming similarity of these two taxa, considered the former species a synonym of Physaria wardii (S. Watson) O'Kane \& Al-Shehbaz as P. kingii var. parvifolia (Maguire \& A. H. Holmgren) S. L. Welsh, which was referred to as $P$. kingii subsp. latifolia (A. Nelson) O'Kane \& AlShehbaz by Al-Shehbaz and O'Kane (2002). Furthermore, Al-Shehbaz and I (2002) considered Lesquerella kaibabensis Rollins indistinguishable from P. wardii. After further review of specimens and photographs, I find that I agree with Holmgren (2005) in that $P$. kaibabensis (Rollins) N. H. Holmgren should be recognized, but differently as an infraspecific taxon of $P$. kingii. Additionally, the similarities of $P$. utahensis (Rydberg) O'Kane \& Al-Shehbaz to $P$. kingii have been followed by both Holmgren (2005) and Welsh (2003; referring to P. wardii). A key to the subspecies of $P$. kingii follows.

Key tO THE SUBSPECHS OF PMYSARIA KINGI

la. Valves of the silicle mostly pubescent on the inside; silicle slightly broader than long, the apex Iruncate or reluse.

2a. Basal leaf blades sinuate or lobed, often lyrate; plants of northeastern Oregon . . P. kingii subsp. diversifolia (Greene) O’Kane \& Al-Shehbaz

2b. Basal leaf blades \pm entire (may be slightly lobed or widened at the blade base); plants of eastern California and Nevada ... . . . . . . ........... k. kingii subsp. kingii 
1b. Valves of the silicle glabrous on the inside; silicle as wide as long or longer than wide, the apex rounded-acute.

3a. Pedicels recurved in a single arch or recurved and slightly sigmoid; plants of northern Nevada, southeastern Oregon, southern and northern (but apparently not central) Idaho ......... ............. . kingii subsp. cobrensis (Rollins \& E. A. Shaw) O'Kane \& Al-Shehbaz

3b. Pedicels straight or sigmoid, but not recurved. 4a. Petals pure white, $4.5-8.5 \mathrm{~mm}$ long; mature styles less than $2 \mathrm{~mm}$ long; endemic to the Kaibab Plateau of northern Arizona ....... . kingii subsp. kaibabensis

4b. Petals yellow (occasionally cream-yellow or cream-white on the Kaibab Plateau of northern Arizona), 6-13 mm long; mature styles greater than (2)2.5 mm long; northern Arizona (including the Kaibab Plateau), California, Nevada, and Utah. 5a. Mature styles 6-9 mm long; ovules 2 to 4 per locule; plants erect; southeastern California .....P. kingii subsp. bernardina (Munz) O'Kane \& Al-Shehbaz.

5b. Mature styles (2-)2.5-6 mm long; ovules 2 to 8 per locule; plants erect to prostrate.

6a. Raceme not secund in fruit; silicle \pm densely pubescent; seeds usually 4 to 8 per locule; plants erect to prostrate; eastern California, northern Arizona, southern half of Nevada, and Utah................ ..... P. kingii subsp. latifolia (A. Nelson) O'Kane \& Al-Shehbaz

6b. Raceme secund in fruit; silicle sparsely pubescent; seeds usually 2 per locule; plants prostrate; northern Utah . . . . . . ..... P. kingii subsp. utahensis

\section{PHYSARIA LEPIDOTA}

Physaria lepidota Rollins subsp. membranacea (Rollins) O'Kane, stat. nov. Basionym: Physaria membranacea Rollins, Brittonia 33: 335. 1981. TYPE: U.S.A. Utah: Kane Co., steep chip-rock slide, 1/4 mi. W of jet. of Utah Hwy. 15 \& U.S. Hwy. 89, betw. Kanab \& Zion Natl. Park, 20 mi. E of park entrance, 10 June 1979, R. C. Rollins \& K. W. Rollins 79198 (holotype, GH; isotypes, BRY, NY, RM, UC, US).

A key to the taxa of Physaria chambersii Rollins is given in Holmgren (2005), treated as varieties. It is probable that $P$. lepidota subsp. membranacea is a stabilized hybrid, perhaps ancient, between $P$. lepidota subsp. lepidota and one of the infraspecies of P. chambersii. As such, P. lepidota subsp. membranacea could as easily be accommodated as a subspecies of $P$. chambersii rather than of $P$. lepidota. Rollins (1981) was apparently cognizant of this situation when he transferred his $P$. chambersii var. membranacea Rollins to P. lepidota var. membranacea (Rollins) Rollins. Here I have chosen to focus on the trichome rays, which are fused for about half their length (they are nearly fully fused in P. lepidota), a rare characteristic in the genus.

\section{PHYSARIA NEWBERRYI}

Physaria newberryi A. Gray subsp. yesicola (R. C. Sivinski) O'Kane, stat. nov. Basionym: Physaria newberryi var. yesicola R. C. Sivinski, Sida 18: 673. 1999. TYPE: U.S.A. New Mexico: Valencia Co., T6N R3W, Sec. 2 NW 1/4 of NW 1/4, NE side of Sierra Lucero ca. $37 \mathrm{~km}$ W of Los Lunas, 4. May 1998, R. Sivinski \& McDonald 4335 (holotype, UNM; isotypes, ARIZ, BRY, CAS, GH, ISTC, MO, NY, US).

\section{Physara saximontana}

Physaria saximontana Rollins subsp. dentata (Rollins) O'Kane, stat. nov. Basionym: Physaria saximontana Rollins var. dentata Rollins, Contr. Gray Herb. 214: 14. 1984. TYPE: U.S.A. Montana: Lewis \& Clark Co., on upper E slope of $\mathrm{mtn}$. S of Solk Lake, $8100 \mathrm{ft}$., Bob Marshall Wilderness, SE 1/4 sec. 31, T24N, R11W, 26 July 1979, K. H. Lackschewitz 9106 (holotype, $\mathrm{GH}$; isotype, MONTU).

A key to the two subspecies of Physaria saximontana is given in Rollins (1993), as varieties.

Acknowledgments. I am grateful to Tom and Jim Van Soelen, of San Juan Outfitters, Durango, Colorado, for guiding me and my companions into the Weminuche Wilderness on horseback. The world needs a "Cooking with Cowboy Tom" television show. San Juan College, Farmington, New Mexico, generously provided funding for the collecting trip. Roy Gereau rendered the diagnosis into Latin. John Keller, Colorado Geological Survey, and David Gonzales, Fort Lewis College, helped in identifying the new species' geologic substrate. I also thank my long-time field companions Ken Heil and Dave Jamieson and our "plant wrangler" Wayne Mietty. Comments by Ihsan Al-Shehbaz, James Harris, and Victoria Hollowell greatly improved the manuscript.

\section{Literature Cited}

Al-Shehbaz, I. A. \& S. L. O'Kane Jr. 2002. Lesquerella is united with Physaria. Novon 12: 319-329.

Anderson, J. L., J. L. Reveal \& R. C. Rollins. 1997. Lesquerella vicina (Brassicaceae), a new species from the Uncompahgre Valley in western Colorado. Novon 7: 9-12. 
Heil, K. D. \& S. L. O'Kane Jr. 2003. Catalog of the Four Corners flora: Vascular plants of the San Juan River Drainage, Arizona, Colorato, New Mexico, and Utah. Harvard Pap. Bot. 7: 321-379.

Holmgren, N. H. 2005. Brassicaceae. Pp. 174-118 in N. H. Holmgren, P. K. Holmgren \& A. Cronquist (editors). Intermountain Flora, Vol. 2. Part B. New York Botanical Garden, Bronx.

IUCN. 2001. IUCN Red list Calegories and Criteria Version 3.1. IUCN Species Survival Commission. IUCN, Gland. Switzerland, and Cambridge, United Kingdom.

Mulligan, G. A. 1968. Transfers from Physaria to Lesquerella (Cruciferae). Canad. J. Bot. 47: 21.5-217.

O’Kane, S. L., Jr. 1999. Lesquerella navajoensis (Brassica(ceae), a new species of the $L$. hitchcoctii complex from New Mexico. Madroño 46: 88-91.

\& J. L. Reveal. 2006. Physaria pulvinata (Brassica(ceae), a new species from southwestern Colorado. Brittonia 58: 74-77.
Rollins. R. C. 1981. Studies in the genus Physaria (Cruciferae). Brittonia 33: 332-341.

1993. The Cruciferae of Continental North America. Stanford Univ. Press. Stanford.

\& E. A. Shaw. 1973. The Genus lesquerella (Cruciferae) in North America. Ilarvard Univ. Press, Cambridge.

Steven, T. A.. P. W. I.ipman, W. J. Hail Jr., F. Barker \& R. G. lacdke. 1974. Geologic map of the Durango Quadrangle, southwestern Colorado. U.S. Geol. Surv.. Misc. Investigaltions Ser., Map 1-764.

Weber. W. A. 2003. The Middle Asian Element in the Southern Rocky Mountain Flora of the westem United States: A critical biogeographical review. J. Biogeogr. 30: 619-685.

Welsh. S. L. 2003. Cruciferae. Pp. 249-300 in S. I. Welsh, N. D. Alwood, S. Goodrich \& I. C. Higgins (editors). A Utah Flora, 3rd ed.. revised. Brigham Young University. Provo. Westem Geographies. 1991. Colorado Geologic Ilighway Map. Westem Geographies, Canon City, Colorado. 

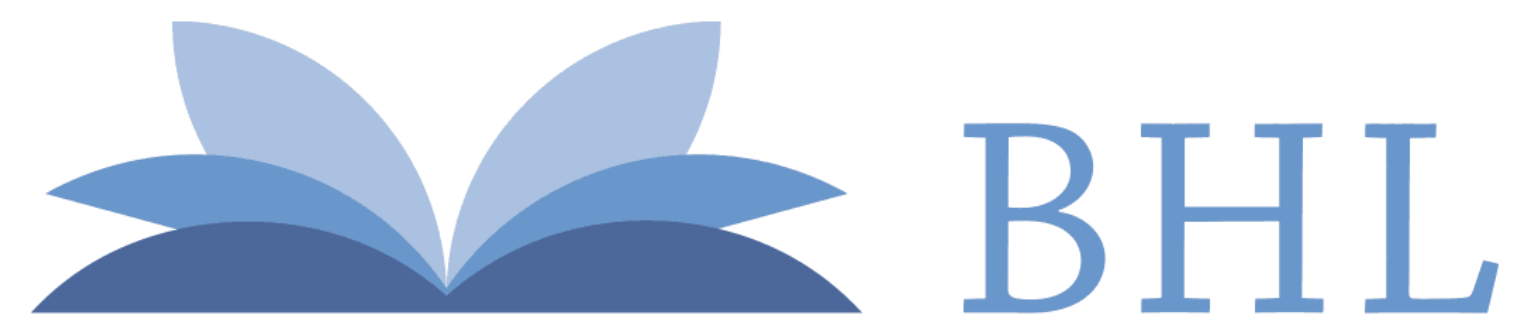

\section{Biodiversity Heritage Library}

O'Kane, Steve L. 2007. "Physaria scrotiformis (Brassicaceae), a new high-elevation species from southwestern Colorado and new combinations in Physaria." Novon a journal of botanical nomenclature from the Missouri Botanical Garden 17, 376-382. https://doi.org/10.3417/1055-3177(2007)17[376:PSBANH]2.0.CO;2.

View This Item Online: $\underline{\text { https://www.biodiversitylibrary.org/item/41805 }}$ DOI: https://doi.org/10.3417/1055-3177(2007)17[376:PSBANH]2.0.CO;2 Permalink: https://www.biodiversitylibrary.org/partpdf/17567

\section{Holding Institution}

Missouri Botanical Garden, Peter H. Raven Library

\section{Sponsored by}

Missouri Botanical Garden

\section{Copyright \& Reuse}

Copyright Status: In copyright. Digitized with the permission of the rights holder.

License: http://creativecommons.org/licenses/by-nc-sa/3.0/

Rights: https://biodiversitylibrary.org/permissions

This document was created from content at the Biodiversity Heritage Library, the world's largest open access digital library for biodiversity literature and archives. Visit BHL at https://www.biodiversitylibrary.org. 